DOI : https://doi.org/10.24843/JFU.2021.v10.i01.p13

pISSN: 2301-7716; eISSN: 2622-4607

Jurnal Farmasi Udayana, Vol 10, No 1, Tahun 2021, 107 - 116

\title{
Aktivitas Antimikroba Dan Antioksidan Ekstrak Dan Fraksi Daun Tembelekan (Lantana camara L.)
}

\author{
Wahyuningrum $R^{1}$, Genatrika $E^{1}$, Pahalawati IN ${ }^{1}$ \\ ${ }^{1}$ Fakultas Farmasi Universitas Muhammadiyah Purwokerto, Jalan Raya KH. Ahmad Dahlan, \\ Purwokerto, 53182 \\ E-mail: retnowahyuningrum@ump.ac.id
}

Riwayat artikel: Dikirim: 14/01/2021; Diterima: 20/04/2021, Diterbitkan: 1/07/2021

\begin{abstract}
Lantana camara is a medicinal plant belongs to family Verbenaceae. It is widely used as traditional medicine for treating various health problems. But there has been no report about potential activity of $L$. camara that grow in Indonesia and its fractions. The aim of this research were to investigate the antimicrobial activity of extract and its fractions of L. camara leaves. Extract was prepared by maceration in ethanol $(96 \%)$ then fractionated using n-hexane and ethyl acetate. Antimicrobial activity was carried out using agar difussion method and antioxidantactivity was carried out using DPPHradical scavenging activity assay. Concentration of extract and fraction tested were 12,5 $\mu \mathrm{g} / \mathrm{mL} ; 25 \mu \mathrm{g} / \mathrm{mL} ; 50 \mu \mathrm{g} / \mathrm{mL}$; and $100 \mu \mathrm{g} / \mathrm{mL}$. The result showed that extract and fraction of L. camara leaves exhibit strong antibacterial activity against Gram positive bacteria (Bacillus subtilis, Staphylococcus aureus), weak inhibition against Gram negative bacteria (Escherichia coli), and and were not able to inhibit the growth of Candida albicans. The ethanolic extract of $L$. camara leaves and its fractions had antioxidant activity. DPPH radical scavenging assay showed the IC50 value of 8.95 $\mu \mathrm{g} / \mathrm{mL}$ for ethanolic extract
\end{abstract}

Keywords : Lantana camara, extract, fraction, antioxidant, antimicrobial

\begin{abstract}
ABSTRAK
Lantana camara L.(Tembelekan) adalah tanaman anggota suku Verbenaceae yang dikenal oleh masyarakat untuk mengobati berbagai penyakit. Namun, hingga saat ini, penelitian terhadap potensi $L$. camara yang tumbuh di Indonesia belum banyak dilakukan. Tujuan dari penelitian ini adalah untuk mengetahui aktivitas antimikroba ekstrak dan fraksi daun $L$. camara serta untuk mengetahui aktivitas antioksidannya. Simplisia daun L. camara diekstraksi dengan metode maserasi menggunakan pelarut etanol $96 \%$. Ekstrak kemudian difraksinasi dengan pelarut n-heksana dan etil asetat. Pengujian aktivitas antimikroba menggunakan metode difusi agar dengan konsentrasi uji sebesar $12,5 \mu \mathrm{g} / \mathrm{mL} ; 25 \mu \mathrm{g} / \mathrm{mL} ; 50$ $\mu \mathrm{g} / \mathrm{mL}$; dan $100 \mu \mathrm{g} / \mathrm{mL}$. Uji aktivitas antioksidan dilakukan dengan metode penangkapan radikal bebas DPPH. Hasil penelitian menunjukkan bahwa ekstrak dan fraksi ekstrak daun $L$. camara memberikan penghambatan kuat terhadap bakteri Gram positif (Bacillus subtilis, Staphylococcus aureus), penghambatan lemah terhadap bakteri Gram negative (Escherichia coli), dan tidak mampu menghambat pertumbuhan terhadap jamur Candida albicans. Ekstrak etanol daun L. camara dan fraksinya memiliki aktivitas antioksidan melalui penangkapan radikal bebas DPPH dengan nilai $\mathrm{IC}_{50}$ ekstrak sebesar $8,95 \mu \mathrm{g} / \mathrm{mL}$.
\end{abstract}

Kata kunci: Lantana camara; ekstrak; fraksi; antioksidan; antimikroba 
DOI : https://doi.org/10.24843/JFU.2021.v10.i01.p13

pISSN: 2301-7716; eISSN: 2622-4607

Jurnal Farmasi Udayana, Vol 10, No 1, Tahun 2021, 107 - 116

\section{PENDAHULUAN}

Penyakit yang disebabkan infeksi dari bakteri masih menjadi suatu permasalahan yang cukup serius di Indonesia. Di Indonesia prevalensi penyakit yang disebabkan infeksi bakteri masih cukup tinggi. Sudah cukup lama, manusia menggunakan tanaman untuk mengobati berbagai penyakit, termasuk penyakit infeksi. Penelitian ilmiah telah membuktikan berbagai efek terapeutik dari tanaman sehingga banyak masyarakat di dunia yang menggunakan tanaman untuk mengobati penyakit infeksi pada sistem pernapasan, pencernaan maupun sistem urinary (Sharma et al., 2017). Metabolit sekunder yang terdapat baik di di dalam tanaman, hewan, maupun mikroorganisme telah terbukti menjadi sumber kandidat obat baru yang sangat potensial (Thiericke, 2000).

Selain penyakit infeksi, penyakit kronik juga semakin banyak diderita oleh masyarakat modern. Penyakit kronis seperti penyakit kardiovaskuler, diabetes militus, dan penuaan merupakan sebagian contoh penyakit akibat kerusakan oksidatif pada jaringan yang dikarenakan adanya radikal bebas dalam tubuh. Produksi berlebih suatu oksidan atau radikal bebas di dalam tubuh, mempengaruhi patogenesis berbagai penyakit. Antioksidan alami yang dapat diperoleh dari tanaman obat, memainkan peran penting dalam pencegahan dan pengobatan penyakit kronis yang disebabkan oleh stress oksidatif (Zhang et al., 2015). Asupan antioksidan eksogen telah terbukti dapat mencegah inflamasi, aterosklerosis, dan stress oksidatif pada pasien penyakit ginjal kronis (Roumeliotis et al., 2019).

Lantana camara $\mathrm{L}$ atau yang dikenal dengan nama tanaman Tembelekan adalah tanaman yang beberapa bagian tanamannya digunakan untuk mengobati berbagai penyakit. Di Indonesia, tanaman ini juga dikenal sebagai tanaman hias karena bunganya yang indah. Daun dari tanaman ini dimanfaatkan secara empiris oleh masyarakat sebagai obat rematik, ulcer, infeksi, tetanus, kanker, malaria, eksim dan asma (Jamal et al., 2018). Selain itu, masyarakat Uganda juga menggunakan daunnya untuk mengobati gejala penyakit tuberkulosis (Kirimuhuzya et al., 2009). Diduga, senyawa golongan flavonoid dari tanaman ini yang bertanggung jawab terhadap aktivitas antimycobacteriumnya (Begum et al., 2008).

Namun, hingga saat ini, penelitian terhadap potensi $L$. camara yang tumbuh di Indonesia belum banyak dilakukan. Pembuktian khasiat secara ilmiah dan penelusuran kandungan kimia dari tanaman ini, khususnya yang ada di Indonesia masih sedikit dilakukan. Pada penelitian ini dilakukan penelusuran aktivitas antimkroba dan antioksidan dari daun L. camara sebagai pembuktian ilmiah khasiat tanaman ini untuk mengobati penyakit infeksi dan penyakit akibat radikal bebas. Uji aktivitas antimikroba dan antioksidan dilakukan secara in vitro terhadap ekstrak etanol dan fraksi daun $L$. camara.

\section{BAHAN DAN METODE}

\section{Bahan dan Alat}

\section{Bahan}

Simplisia daun L. camara (diperoleh dari Sleman, Yogyakarta), etanol 96\% (Bratachem), etanol pro analisis (Merck), metanol pro analisis (Merck), etil asetat pro analisis (Merck), silika gel $60 \mathrm{~F}_{254}$ (Merck), serium sulfat (Merck), dimetilsulfoksida, air suling, DPPH (Merck), media Nutrient Agar (NA, Difco), Media Nutrient Broth (NB, Difco), Potato Dextrose Agar (PDA), Potato Dextrose Broth (PDB). Mikroba uji yang digunakan adalah Bacillus subtilis ATCC 6633, Staphylococcus aureus ATCC 25923, Eschericia coli ATCC 35218, dan 
DOI : https://doi.org/10.24843/JFU.2021.v10.i01.p13

pISSN: 2301-7716; eISSN: 2622-4607

Jurnal Farmasi Udayana, Vol 10, No 1, Tahun 2021, 107 - 116

Candida albicans ATCC 10231 yang diperoleh dari LaboratoriumMikrobiologi Universitas Muhammadiyah Purwokerto (UMP).

\section{Prosedur ekstraksi}

Serbuk daun L.camara (190 g) diekstraksi dengan menggunakan metode maserasi dengan pelarut etanol 96\% (1:10). Ekstrak etanol yang diperoleh $\left(\begin{array}{ll}10 & \mathrm{~g}\end{array}\right)$ difraksinasi dengan menggunakan pelarut n-heksan (1:2) sehingga diperoleh 2 kelompok fraksi, yaitu fraksi larut nheksana dan fraksi tidak larut n-heksana. Selanjutnya, Fraksi tidak larut n-heksana (4 g) difraksinasi kembali dengan menggunakan pelarut etil asetat (1:2) sehingga diperoleh 2 kelompok fraksi, yaitu fraksi larut etil asetat dan fraksi tidak larut etil asetat.

\section{Uji aktivitas antimikroba}

Aktivitasantimikroba

dari ekstraketanol dan semua fraksi diuji dengan menggunakan metode difusi agar sesuai dengan prosedur uji yang dilakukan (Wahyuningrum et al., 2016)]. Sebanyak $100 \mu \mathrm{L}$ suspensi mikroba dalam larutan steril $\mathrm{NaCl} 0,9 \%$ yang mengandung setara $1 \times 10^{8} \mathrm{CFU} / \mathrm{mL}$ bakteri dan jamur uji diinokulasikan secara pour plate ke dalam cawan petri steril yang berisi media NA atau SDA. Kertas cakram $(6 \mathrm{~mm})$ ditetesi sebanyak $10 \mu \mathrm{L}$ larutan sampel ekstrak etanol dan fraksi $(12,5 ; 25 ; 50$; dan 100 $\mu \mathrm{g} / \mathrm{mL}$ ). Kontrol negatif yang digunakan adalah etanol absolut. Kontrol positif berupa ciproflokasin $(2 \mu \mathrm{g} / \mu \mathrm{L})$ terhadap bakteri uji dan ketokonazol $(0,1 \% \mathrm{~b} / \mathrm{v})$ terhadap jamur uji. Dilakukan inkubasi dengan menggunakan alat inkubator suhu $37^{\circ} \mathrm{C}$ selama 24 jam untuk bakteri uji dan 48 jam untuk jamur. Aktivitas antimikroba ditentukan dengan mengukur terbentuknya diameter zona hambat ( $\mathrm{mm})$.

\section{Uji Aktivitas Antioksidan}

Ekstrak etanol dan fraksi ekstrak daun L.camara masing-masing dilarutkan dalam metanol p.a dengan konsentrasi 2,5; 5,$0 ; 7,5 ; 10,0$; dan $12,5 \mu \mathrm{g} / \mathrm{mL}$. Sebanyak 2 mL Larutan DPPH 30 ppm dimasukkan ke dalam vial, kemudian ditambahkan masing-masing ekstrak dan fraksi dengan berbagai konsentrasi sebanyak $1 \mathrm{~mL}$. Campuran larutan DPPH dan sampel diinkubasi dalam ruang gelap selama waktu optimum/operating time (OT) yaitu 30 menit. Serapan campuran tersebut dibaca pada panjang gelombang maksimum, yaitu $516 \mathrm{~nm}$. Daya penghambatan dihitung dalam persen peredaman (\% inhibisi) terhadap radikal DPPH dengan menggunakan rumus, yaitu: $\%$ Inhibisi $=\frac{\text { Abs. Kontrol }- \text { Abs. Sampel }}{\text { Abs. Kontrol }} \times 100 \%$

Perolehan data persen inhibisi terhadap radikal bebas DPPH pada variasi konsentrasi selanjutnya digunakan untuk menentukan nilai $\mathrm{IC}_{50}$ sampel. Penentuan nilai $\mathrm{IC}_{50}$ dengan menggunakan persamaan regresi linear $\mathrm{y}=\mathrm{bx}+\mathrm{a}$, dengan nilai $\mathrm{y}$ sebesar 50 dan nilai x sebagai $\mathrm{IC}_{50}$.

\section{HASIL}

Hasil fraksinasi diperoleh 4 fraksi yang berbeda yaitu fraksi larut n-heksana, fraksi tidaklarut $n$-heksana, fraksi larut etil asetat dan fraksi tidak larut etil asetat. Bobot ekstrak dan fraksi yang diperoleh dapat dilihat pada Tabel 1. Fraksinasi ekstrak etanol daun L.camara dilakukan dengan metode fraksinasi padat-cair dengan menggunakan 2 pelarut yang berbeda sifat kepolarannya yaitu pelarut nheksan sebagai pelarut non-polar dan etil asetat sebagai pelarut semi-polar. Fraksinasi ekstrak daun $L$. camara bertujuan untuk memisahkan senyawa berdasarkan kelarutannya terhadap pelarut dengan tingkat kepolaran yang berbeda. Hal ini akan bermanfaat bagi arah 
DOI : https://doi.org/10.24843/JFU.2021.v10.i01.p13

pISSN: 2301-7716; eISSN: 2622-4607

Jurnal Farmasi Udayana, Vol 10, No 1, Tahun 2021, 107 - 116

penelitian selanjutnya untuk tujuan isolasi senyawa aktif dari tanaman ini. Senyawa non-polar yang berada pada ekstrak etanol daun L. camara akan tertarik kedalam pelarut n-heksan dan senyawa yang bersifat semi polar akan tertarik pada pelarut etil asetat.

Tabel 1. Bobot ekstrak dan fraksi daun L.camara

\begin{tabular}{clcc}
\hline No. & \multicolumn{1}{c}{ Bahan } & Bobot (gram) & Rendemen $(\%)$ \\
\hline 1. & Ekstrak etanol & 31,97 & 16,82 \\
2. & Fraksi Larut n-heksana & 2,45 & 24,5 \\
3. & Fraksi Tidak Larut n-heksana & 6,78 & 67,8 \\
4. & Fraksi Larut Etil Asetat & 1,43 & 35,75 \\
5. & Fraksi Tidak Larut Etil Asetat & 2,49 & 62,25 \\
\hline
\end{tabular}

Aktivitas antimikroba dari ekstrak dan fraksi daun L.camara disajikan pada Tabel 2. Hasil penelitian menunjukkan bahwa ekstrak dan fraksi daun L.camara memiliki aktivitas lebih baik dalam menghambatpertumbuhan bakteri Gram positif dibandingkan terhadap bakteri Gram negatif dan jamur.

Tabel 2. Hasil uji aktivitas antimikroba ekstrak dan fraksi daun L.camara

\begin{tabular}{|c|c|c|c|c|c|}
\hline \multirow[t]{2}{*}{ Nama Sampel } & \multirow{2}{*}{$\begin{array}{c}\text { Mikroba } \\
\text { Uji }\end{array}$} & \multicolumn{4}{|c|}{ Rata-rata diameter zona hambat $(\mathrm{mm})$} \\
\hline & & $12,5 \mu \mathrm{g} / \mathrm{mL}$ & $25 \mu \mathrm{g} / \mathrm{mL}$ & $50 \mu \mathrm{g} / \mathrm{mL}$ & $100 \mu \mathrm{g} / \mathrm{mL}$ \\
\hline \multirow[t]{4}{*}{ Ekstrak etanol } & B. subtilis & $18,84 \pm 2,57$ & $19,58 \pm 2,72$ & $21,48 \pm 0,47$ & $26,42 \pm 4,29$ \\
\hline & S. aureus & $14,19 \pm 1,08$ & $18,68 \pm 1,08$ & $20,11 \pm 1,21$ & $24,04 \pm 1,15$ \\
\hline & E. coli & - & - & - & $7,58 \pm 0,81$ \\
\hline & C. albicans & - & - & - & - \\
\hline \multirow{3}{*}{$\begin{array}{l}\text { Fraksi larut n- } \\
\text { heksana }\end{array}$} & B.subtilis & $15,10 \pm 4,20$ & $16,32 \pm 4,85$ & $18,99 \pm 5,39$ & $19,78 \pm 4,93$ \\
\hline & S.aureus & $18,08 \pm 1,56$ & $21,55 \pm 1,01$ & $23,08 \pm 1,24$ & $23,48 \pm 1,05$ \\
\hline & $\begin{array}{l}\text { E.coli } \\
\text { C.albicans }\end{array}$ & - & - & - & - \\
\hline \multirow{2}{*}{$\begin{array}{l}\text { Fraksi tidak } \\
\text { larut n-heksana }\end{array}$} & B. subtilis & $16,73 \pm 0,08$ & $20,48 \pm 2,43$ & $20,78 \pm 2,68$ & $22,65 \pm 2,18$ \\
\hline & $\begin{array}{l}\text { S.aureus } \\
\text { E.coli } \\
\text { C.albicans }\end{array}$ & $\begin{array}{c}16,02 \pm 3,38 \\
-\end{array}$ & $\begin{array}{c}17,54 \pm 3,62 \\
-\end{array}$ & $\begin{array}{c}20,63 \pm 2,11 \\
-\end{array}$ & $\begin{array}{c}23,49 \pm 0,47 \\
6,99 \pm 0,30\end{array}$ \\
\hline \multirow{4}{*}{$\begin{array}{l}\text { Fraksi larut etil } \\
\text { asetat }\end{array}$} & B.subtilis & $19,42 \pm 1,13$ & $20,24 \pm 0,99$ & $20,57 \pm 0,78$ & $22,09 \pm 1,67$ \\
\hline & S.aureus & $11,58 \pm 0,97$ & $13,52 \pm 0,35$ & $15,82 \pm 0,51$ & $18,16 \pm 0,89$ \\
\hline & E.coli & - & - & - & $7,07 \pm 0,12$ \\
\hline & C.albicans & - & - & - & - \\
\hline Fraksi tidak & B.subtilis & - & - & - & $13,34 \pm 1,77$ \\
\hline \multirow[t]{2}{*}{ larut etil asetat } & S.aureus & $10,72 \pm 0,89$ & $11,48 \pm 1,50$ & $13,72 \pm 2,44$ & $18,13 \pm 1,73$ \\
\hline & $\begin{array}{l}\text { E.coli } \\
\text { C.albicans }\end{array}$ & - & - & - & - \\
\hline \multirow{2}{*}{$\begin{array}{l}\text { Ciprofloxacin } 2 \\
\mu \mathrm{g} / \mu \mathrm{L}\end{array}$} & B.subtilis & \multicolumn{4}{|c|}{$41,38 \pm 1,23$} \\
\hline & $\begin{array}{l}\text { S.aureus } \\
\text { E.coli }\end{array}$ & \multicolumn{4}{|c|}{$34,73 \pm 1,20$} \\
\hline $\begin{array}{l}\text { Ketokonazol } \\
0,1 \%\end{array}$ & C.albicans & \multicolumn{4}{|c|}{$33,41 \pm 1,14$} \\
\hline
\end{tabular}

Ekstrak etanol daun L.camara memiliki kemampuan dalam meredam radikal bebas paling tinggi yaitu 51,58\% pada konsentrasi $12,5 \mu \mathrm{g} / \mathrm{mL}$. Hasil uji 
DOI : https://doi.org/10.24843/JFU.2021.v10.i01.p13

pISSN: 2301-7716; eISSN: 2622-4607

Jurnal Farmasi Udayana, Vol 10, No 1, Tahun 2021, 107 - 116

aktivitasantioksidan ekstrak etanol dan fraksi daun L.camara dapat dilihat pada tabel 3 dan 4 . $\mathrm{IC}_{50}$ merupakan konsentrasi antioksidan yang mampu menghambat $50 \%$ DPPH sebagai radikalbebas. Nilai ini digunakan untuk membandingkan aktivitas antioksidan dari berbagai sampel atau senyawa. Berdasarkan nilai $\mathrm{IC}_{50}$ dari semua sampel, diketahui bahwa semua sampel memiliki nilai $\mathrm{IC}_{50}<70 \mu \mathrm{g} / \mathrm{mL}$. Ekstrak etanol daun L.camara memiliki nilai $\mathrm{IC}_{50}$ terkecil, yaitu $8,95 \mu \mathrm{g} / \mathrm{mL}$, lebih besar dibandingkan dengan nilai $\mathrm{IC}_{50}$ vitamin C sebesar 3,99 $\mu \mathrm{g} / \mathrm{mL}$.

Hasil uji ini menunjukkan bahwa fraksi tidak larut dalam etil asetat memiliki nilai $\mathrm{IC}_{50}$ yang paling rendah yaitu $23,86 \mu \mathrm{g} / \mathrm{mL} \mathrm{m}$ dan fraksi larut dalam etil asetat memiliki nilai $\mathrm{IC}_{50}$ yang paling tinggi yaitu $68,43 \mu \mathrm{g} / \mathrm{mL}$. Hal ini menunjukkan bahwa fraksi tidak larut dalam etil asetat merupakan fraksi potensial yang memiliki aktivitas antioksidan. Nilai IC $_{50}$ ekstrak dan fraksi ekstrak dapat dilihat pada Tabel 4.

Tabel 3. Persentase rerata redaman radikal bebas dari ekstrak dan fraksi daun L.camara

\begin{tabular}{cccccc}
\hline $\begin{array}{c}\text { Konsentrasi } \\
(\mu \mathrm{g} / \mathrm{mL})\end{array}$ & \multicolumn{4}{c}{ Rerata Peredaman Radikal Bebas \pm SD $(\%)$} \\
\cline { 2 - 6 } & Ekstrak & $\begin{array}{c}\text { Fraksi larut n- } \\
\text { heksana }\end{array}$ & $\begin{array}{c}\text { Fraksi tidak larut } \\
\text { n-heksana }\end{array}$ & $\begin{array}{c}\text { Fraksi larut Etil } \\
\text { Asetat }\end{array}$ & $\begin{array}{c}\text { Fraksi tidak larut } \\
\text { Etil Asetat }\end{array}$ \\
\hline 2,5 & $46,91 \pm 0,85$ & $11,65 \pm 0,19$ & $22,59 \pm 0,09$ & $32,26 \pm 1,004$ & $35,75 \pm 1,004$ \\
5 & $48,19 \pm 0,73$ & $14,04 \pm 1,42$ & $24,48 \pm 0,25$ & $32,98 \pm 1,26$ & $37,30 \pm 1,109$ \\
7,5 & $49,69 \pm 1,04$ & $15,09 \pm 1,34$ & $26,54 \pm 0,49$ & $32,69 \pm 1,01$ & $39,14 \pm 1,109$ \\
10 & $50,47 \pm 1,06$ & $16,71 \pm 1,59$ & $28,70 \pm 0,33$ & $34,14 \pm 1,26$ & $40,69 \pm 1,15$ \\
12,5 & $51,58 \pm 1,08$ & $17,93 \pm 1,83$ & $31,09 \pm 0,35$ & $35,03 \pm 0,88$ & $42,41 \pm 0,94$ \\
\hline
\end{tabular}

Tabel 4. Nilai IC50 ekstrak dan fraksi daun L.camara

\begin{tabular}{cc}
\hline Sampel & IC $_{\mathbf{5 0}} \mathbf{\pm} \mathbf{S D}(\boldsymbol{\mu g} / \mathrm{mL})$ \\
\hline Ekstrak Etanol & $8,95 \pm 2,07$ \\
Fraksi larut n-heksana & $67,86 \pm 18,00$ \\
Fraksi tidak larut n-heksana & $35,03 \pm 1,51$ \\
Fraksi larut Etil Asetat & $68,43 \pm 3,22$ \\
Fraksi tidak larut Etil Asetat & $23,86 \pm 1,60$ \\
Vitamin C & $3,99 \pm 0,25$ \\
\hline
\end{tabular}

\section{PEMBAHASAN}

Ekstrak dan fraksi daun L.camara memiliki aktivitas lebih baik dalam menghambatpertumbuhan bakteriGram positif dibandingkan terhadap bakteri Gram negatif dan jamur. Hal tersebut sesuai dengan penelitian sebelumnya yang menyebutkan bahwa L.camara yang tumbuh di Himalaya tidak dapat menghambat pertumbuhan E.coli (Zulqarnain et al., 2015). Ekstrak L. camara dari tanaman yang tumbuh di India juga menunjukkan tidak adanya aktivitas antibakteri terhadap E. coli (V. P. Kumar et al., 2006). Ekstrak etanol memberikan aktivitas antibakteri yang lebih kuat daripada fraksinya. Hal ini mungkin disebabkan karena senyawa metabolit sekunder dalam ekstrak yang aktif sebagai antibakteri lebih banyak dibandingkan di dalam fraksi.

Daun L. camara mengandung senyawa-senyawa fenolik seperti kuersetin, ruti, asam galat, asam kafeat, dan asam klorogenat (Sousa et al., 2015). Senyawa asam fenolat mampu merusak struktur membran sitoplasma sehingga menyebabkan kematian sel bakteri (Sanhueza et al., 2017). Tanaman ini juga dilaporkan memiliki senyawa triterpen pentasiklik bernama lantandene A (GraceLynn et al., 2012). Penelitian sebelumnya melaporkan bahwa L. camara mengandung 
DOI : https://doi.org/10.24843/JFU.2021.v10.i01.p13

pISSN: 2301-7716; eISSN: 2622-4607

Jurnal Farmasi Udayana, Vol 10, No 1, Tahun 2021, 107 - 116

minyak atsiri dan komponen kimia minya atsiri yang bertanggung jawab terhadap aktivitas antibakteri adalah the $\beta$ caryophyllene and (E)-nerolidol (Satyal P et al., 2016). Sedangkan penelitian lain menyebutkan bahwa parthenin, suatu senyawa seskuiterpen lakton merupakan senyawa dalam $L$. camara yang memiliki aktivitas antibakteri terhadap E.coli, $P$. aeruginosa, B. subtilis and E. fecalis (Pradeep BV et al., 2013). Mekanisme aksi dari senyawa-senyawa golongan terpenoid adalah dengan mempengaruhi membran sel dan dinding sel mikroba. Sifat lipofilik senyawa golongan terpen menjadi faktor penting terhadap afinitas senyawa terpenoid pada membran fosfolipid bilayer. Dengan kata lain, membran sel bakteri menjadi tempat aksi dari senyawa golongan terpenoid dan aktivitas antibakterinya dipengaruhi oleh sifat lipofilik dari senyawa terpenoid (Wink, 2015).

Seluruh sampel, baik ekstrak dan fraksi tidak menunjukkan aktivitas antifungi terhadap C. albicans. Hasil ini berbeda dengan yang dilaporkan sebelumnya. L. camara yang tumbuh di India dilaporkan mampu menghambat pertumbuhan $C$. albicans (V. P. Kumar et al., 2006).

Aktivitas antioksidan ekstrak dan fraksi dilakukan dengan menggunakan metode DPPH sebagai radikal bebas. DPPH merupakan radikal bebas yang telah digunakan secara luas dalam penelitian untuk mengetahui aktivitas antioksidan berbagai senyawa, termasuk senyawa dari bahan alam. Parameter yang diukur pada metode ini adalah $\mathrm{IC}_{50}$ atau $\mathrm{EC}_{50}$. Meskipun $\mathrm{EC}_{50}$ terhadap DPPH dianggap sebagai parameter yang tidak sesuai untuk menentukan aktivitas antioksidan karena $\mathrm{IC}_{50}$ tersebut bukan parameter kinetik (Foti, 2015)]. Uji aktivitas antioksidan terhadap sampel dari bahan alam menggunakan DPPH sebagai radikal juga memiliki kelemahan karena adanya pigmen dalam ekstrak tanaman akan berpengaruh terhadap hasil uji (Yeo \& Shahidi, 2019).

Hasil penentuan panjang gelombang maksimum larutan DPPH menunjukkan bahwa panjang gelombang maksimum DPPH pada penelitian ini adalah $516 \mathrm{~nm}$. Hasil tersebut sedikit berbeda dengan penelitian sejenis yang juga menggunakan metode DPPH, dimana panjang gelombang maksimum yang digunakan adalah $517 \mathrm{~nm}$ (S. Kumar et al., 2014; Zhu et al., 2017). Namun, disebutkan bahwa rata-rata panjang gelombang maksimum DPPH adalah pada nilai 515 nm (Foti, 2015). Sedangkan operating time (OT) dari DPPH adalah 30 menit. Panjang gelombang maksimum dan OT ini selanjutnya digunakan dalam pengujian aktivitas antioksidan sampel.

Hasil ini berbeda dengan hasil penelitian aktivitas antioksidan L. camara dari Brazil, dimana tanaman ini memiliki aktivitas antioksidan dengan nilai $\mathrm{IC}_{50}$ sebesar 114,63 $\pm 6,16 \mu \mathrm{g} / \mathrm{mL}$ (Gomes de Melo et al., 2010). Beberapa penelitian aktivitas antioksidan terhadap L.camara yang tumbuh di berbagai wilayah di dunia telah dilakukan.Aktivitas antioksidan dari empat varietas tanaman ini dari India menunjukkan bahwa ekstrak metanol daun memberikan penghambatan terhadap radikal DPPH dengan rentang nilai $\mathrm{IC}_{50}$ 33,30-927,16 $\mu \mathrm{g} / \mathrm{mL}$ (S. Kumar et al., 2014). Sedangkan $\mathrm{IC}_{50}$ ekstrak methanol daun L.camara yang tumbuh di Malaysia adalah sebesar $165 \mu \mathrm{g} / \mathrm{mL}$ (Swamy et al., 2015), dan 16,02 $\mu \mathrm{g} / \mathrm{mL}$ (Mahdi-Pour et al., 2012).

Berdasarkan hal tersebut, $L$. camara memiliki aktivitas antioksidan secara in vitro dengan nilai $\mathrm{IC}_{50}$ yang bervariasi. Perbedaan tersebut dapat terjadi karena perbedaan pelarut yang digunakan. Pada penelitian tersebut, metanol digunakan sebagai pelarut ekstraksi, 
DOI : https://doi.org/10.24843/JFU.2021.v10.i01.p13

pISSN: 2301-7716; eISSN: 2622-4607

Jurnal Farmasi Udayana, Vol 10, No 1, Tahun 2021, 107 - 116

sedangkan pada penelitian ini digunakan etanol sebagai pelarut pada ekstraksi serbuk simplisia daun L.camara. Meski kedua pelarut tersebut merupakan pelarut dari golongan senyawa yang sama, yaitu alkohol, namun perbedaan polaritas dapat mempengaruhi jenis dan banyaknya senyawa dalam serbuk simplisia yang tersari. Perbedaan aktivitas antioksidan dengan menggunakan metode DPPH sebagai radikal bebas dapat disebabkan oleh beberapa hal terkait dengan sistem antioksidan pada prosedur, seperti jenis dan volume pelarut, kandungan air, logam, dan konsentrasi ion hidrogen dalam sistem uji antioksidan (Dawidowicz et al., 2012).

Berdasarkan studi literatur, diketahui bahwa nilai IC $_{50}$ L.camara yang tumbuh di Indonesia dan Malaysia, tidak jauh berbeda, yaitu kurang dari $20 \mu \mathrm{g} / \mathrm{mL}$. Hal ini diduga karena faktor kedekatan letak geografis kedua negara. Faktor geografis dapat mempengaruhi kandungan metabolit sekunder dari suatu tanaman dan tentunya akan berpengaruh terhadap aktivitas biologi tanaman tersebut. Penelitian aktivitas antioksidan terhadap beberapa bagian tanaman ini juga telah dilakukan. Daun merupakan bagian tanaman yang memiliki aktivitas antioksidan terbaik dibandingkan bagian tanaman lain dari L.camara (Mahdi-Pour et al., 2012).

Vitamin C digunakan sebagai kontrol positif dan diperoleh nilai $\mathrm{IC}_{50}$ sebesar 3,99 $\mu \mathrm{g} / \mathrm{mL}$, sedikit lebih besar dibandingkan penelitian terdahulu yang menggunakan vitamin $\mathrm{C}$ sebagai kontrol positif. Sebelumnya, dilaporkan bahwa vitamin $\mathrm{C}$ memiliki aktivitas antioksidan dengan nilai $\mathrm{IC}_{50}$ sebesar $1,65 \mu \mathrm{g} / \mathrm{mL}$ (Wulandari et al., 2020).

Perbedaan penelitian ini dengan penelitian-penelitian yang telah dilakukan sebelumnya adalah dilakukannya uji aktivitas antioksidan fraksi dari ekstrak etanol daun L.camara. Pengujian terhadap fraksi-fraksi yang diperoleh ini bertujuan untuk membandingkan aktivitasnya dengan ekstrak dan juga untuk menelusuri kemungkinan isolasi terhadap senyawa aktifnya.

Hasil pengujian aktivitas antioksidan fraksi juga menunjukkan bahwa aktivitas ekstrak jauh lebih baik dibanding aktivitas seluruh fraksi. Hal tersebut terjadi, diduga karena semua senyawa yang tersari oleh pelarutetanol pada saat proses ekstraksi, masih terkumpul dalam ekstrak dan belum dipisahkan sesuai polaritasnya. Senyawasenyawa yang terdapat dalam ekstrak etanol tersebut berkontribusi terhadap aktivitas antioksidan. Etanol adalah pelarut golongan alkohol yang bersifat polar dan cenderung bersifat tidak selektif, sehingga dapat mengekstraksi berbagai jenis dan golongan metabolit sekunder dalam suatu simplisia, termasuk flavonoid dan senyawa fenolik (Swamy et al., 2015). Terdapat korelasi positif antara kandungan fenolik dalam suatu sampel dengan aktivitas antioksidannya (S. Kumar et al., 2014; Tsai \& Lin, 2019).

Fraksi-fraksi hasil pemisahan ekstrak menunjukkan aktivitas antioksidan yang lebih lemah dibanding ekstrak. Fraksi larut $\mathrm{n}$-heksana memiliki nilai $\mathrm{IC}_{50}$ lebih besar dibanding fraksi tidak larut nheksana. Hal ini mungkin disebabkan kandungan senyawa fenolik yang lebih banyak terdapat dalam fraksi tidak larut nheksana dibandingkan dengan fraksi larut n-heksana. n-heksana merupakan pelarut organik non polar yang akan menarik senyawa-senyawa non polar di dalam ekstrak, seperti senyawa lipid. Senyawa lain yang cenderung lebih polar (termasuk senyawa fenolik) akan tertinggal dalam fraksi tidak larut n-heksana.Dengan demikian, fraksi tidak larut n-heksana memiliki aktivitas antioksidan lebih baik dibanding fraksi larut n-heksana.

Begitu pula dengan fraksi larut etil 
DOI : https://doi.org/10.24843/JFU.2021.v10.i01.p13

pISSN: 2301-7716; eISSN: 2622-4607

Jurnal Farmasi Udayana, Vol 10, No 1, Tahun 2021, 107 - 116

asetat yang memiliki nilai $\mathrm{IC}_{50}$ lebih besar dibanding fraksi tidak larut etil asetat. Hal ini menguatkan bukti bahwa sampel yang mengandung senyawa relatif polar (flavonoid, fenolik) akan memberikan aktivitas antioksidan lebih baik daripada sampel yang lebih non polar. Fraksi tidak larut etil asetat menjadi fraksi paling aktif dengan nilai $\mathrm{IC}_{50}$ terkecil di antara fraksi lain, yaitu 23,86 $\mu \mathrm{g} / \mathrm{mL}$. Namun, aktivitas fraksi tidak larut etil asetat ini tetap lebih lemah jika dibandingkan dengan aktivitas ekstrak.

Berdasarkan hasil tersebut, rekomendasi pengembangan L.camara sebagai obat bahan alam yang memiliki aktivitas antibakteri dan antioksidan adalah dengan menggunakan ekstrak sebagai bahan aktifnya. Hal ini disebabkan karena senyawa metabolit sekunder dalam ekstrak yang aktif sebagai antibakteri maupun antioksidan lebih banyak dibandingkan di dalam fraksi.

\section{KESIMPULAN}

Ekstrak etanol daun L. camara dan fraksinya memiliki aktivitas antibakteri yang baik terhadap bakteri $B$. subtilis, dan $S$. aureus, namun memiliki kemampuan penghambatan yang lemah terhadap bakteri Gram negatif (E. coli). Ekstrak etanol daun $L$. camara dan fraksinya tidak memiliki aktivitas antifungi terhadap $C$. albicans. Ekstrak etanol daun L. camara dan fraksinya memiliki aktivitas antioksidan melalui penangkapan radikal bebas DPPH dengan nilai IC $_{50}$ ekstrak sebesar $8,95 \mu \mathrm{g} / \mathrm{mL}$.

\section{UCAPAN TERIMAKASIH}

Terimakasih kepada Lembaga Penelitian dan Pengabdian Masyarakat Universitas Muhammadiyah Purwokerto yang telah mendanai penelitian ini melalui Hibah Penelitian Fundamental tahun 2018.

\section{DAFTAR PUSTAKA}

Begum, S., Wahab, A., \& Siddiqui, B. S. (2008). Antimycobacterial activity of flavonoids from Lantana

camara Linn. Natural Product

Research, 22(6), 467-470. https://doi.org/10.1080/1478641060 0898714

Dawidowicz, A. L., Wianowska, D., \& Olszowy, M. (2012). On practical problems in estimation of antioxidant activity of compounds by DPPH method (Problems in estimation of antioxidant activity). Food Chemistry, 131(3), 10371043.

https://doi.org/10.1016/j.foodchem.2 011.09 .067

Foti, M. C. (2015). Use and Abuse of the DPPH ${ }^{\bullet}$ Radical. Journal of Agricultural and Food Chemistry, 63(40), 8765-8776. https://doi.org/10.1021/acs.jafc.5b03 839

Gomes de Melo, J., De Sousa Araújo, T.

A., Thijan Nobre de Almeida e Castro, V., Lyra de Vasconcelos Cabral, D., Do Desterro Rodrigues, M., Carneiro do Nascimento, S., Cavalcanti de Amorim, E. L., \& De Albuquerque, U. P. (2010).

Antiproliferative Activity, Antioxidant Capacity and Tannin Content in Plants of Semi-Arid Northeastern Brazil. Molecules, 15(12), 8534-8542. https://doi.org/10.3390/molecules 15 128534

Grace-Lynn, C., Darah, I., Chen, Y., Latha, L. Y., Jothy, S. L., \& Sasidharan, S. (2012). In Vitro Antioxidant Activity Potential of Lantadene A, a Pentacyclic Triterpenoid of Lantana Plants. Molecules, 17(9), 11185-11198. https://doi.org/10.3390/molecules17 
DOI : https://doi.org/10.24843/JFU.2021.v10.i01.p13

pISSN: 2301-7716; eISSN: 2622-4607

Jurnal Farmasi Udayana, Vol 10, No 1, Tahun 2021, 107 - 116

0911185

Irianti, T., Puspitasari, A., Machwiyyah, L., \& Rabbani, H. R. (2016). THE ACTIVITY OF RADICAL SCAVENGING OF 2, 2DIPHENYL-1PYCRILHYDRAZIL (DPPH) BY ETHANOLIC EXTRACTS OF MENGKUDU LEAVES (Morinda citrifolia L.), BROTOWALI STEM (Tinospora crispa L.), ITS WATER FRACTION AND ITS HYDROLIZED FRACTION.

Traditional Medicine Journal, 20(3), 140-148.

Jamal, M., Amir, M., Ali, Z., \& Mujeeb, M. (2018). A comparative study for the extraction methods and solvent selection for isolation, quantitative estimation and validation of ursolic acid in the leaves of Lantana camara by HPTLC method. Future Journal of Pharmaceutical Sciences. https://doi.org/10.1016/j.fjps.2018.0 7.002

Kirimuhuzya, C., Waako, P., Joloba, M., \& Odyek, O. (2009). The antimycobacterial activity of Lantana camara a plant traditionally used to treat symptoms of tuberculosis in South-western Uganda. 9(1), 6.

Kumar, S., Sandhir, R., \& Ojha, S. (2014). Evaluation of antioxidant activity and total phenol in different varieties of Lantana camara leaves. BMC Research Notes, 7(1), 560. https://doi.org/10.1186/1756-05007-560

Kumar, V. P., Chauhan, N. S., Padh, H., \& Rajani, M. (2006). Search for antibacterial and antifungal agents from selected Indian medicinal plants. Journal of Ethnopharmacology, 107(2), 182188. https://doi.org/10.1016/j.jep.2006.03 .013
Mahdi-Pour, B., Jothy, S. L., Latha, L. Y., Chen, Y., \& Sasidharan, S. (2012). Antioxidant activity of methanol extracts of different parts of Lantana camara. Asian Pacific Journal of Tropical Biomedicine, 2(12), 960965. https://doi.org/10.1016/S22211691(13)60007-6

Pradeep BV, Tejaswini M, Nishal P, Pardhu G, Shylaja S, \& Kumar KCh. (2013). Phytochemical screening and antimicrobial activities of plant extract of Lantana camara. 34(3), 645-649.

Roumeliotis, S., Roumeliotis, A., Dounousi, E., Eleftheriadis, T., \& Liakopoulos, V. (2019). Dietary Antioxidant Supplements and Uric Acid in Chronic Kidney Disease: A Review. Nutrients, 11(8), 1911. https://doi.org/10.3390/nu11081911

Sanhueza, L., Melo, R., Montero, R., Maisey, K., Mendoza, L., \& Wilkens, M. (2017). Synergistic interactions between phenolic compounds identified in grape pomace extract with antibiotics of different classes against

Staphylococcus aureus and Escherichia coli. PLoS ONE, 12(2), e0172273. PMC.

https://doi.org/10.1371/journal.pone. 0172273

Satyal P, Crouch RA, \& Monzote L. (2016). The Chemical Diversity of Lantana camara: Analyses of Essential Oil Samples from Cuba, Nepal, and Yemen. 13(3), 336-342.

Sharma, A., Flores-Vallejo, R. del C., Cardoso-Taketa, A., \& Villarreal, M. L. (2017). Antibacterial activities of medicinal plants used in Mexican traditional medicine. Journal of Ethnopharmacology, 208, 264-329. https://doi.org/10.1016/j.jep.2016.04 .045

Sousa, E. O., Miranda, C. M. B. A., 
DOI : https://doi.org/10.24843/JFU.2021.v10.i01.p13

pISSN: 2301-7716; eISSN: 2622-4607

Jurnal Farmasi Udayana, Vol 10, No 1, Tahun 2021, 107 - 116

Nobre, C. B., Boligon, A. A.,

Athayde, M. L., \& Costa, J. G. M.

(2015). Phytochemical analysis and

antioxidant activities of Lantana

camara and Lantana montevidensis

extracts. Industrial Crops and

Products, 70, 7-15.

https://doi.org/10.1016/j.indcrop.201

5.03.010

Swamy, M. K., Sinniah, U. R., \& Akhtar, Mohd. S. (2015). In Vitro

Pharmacological Activities and GC-

MS Analysis of Different Solvent

Extracts of Lantana camara Leaves

Collected from Tropical Region of

Malaysia. Evidence-Based

Complementary and Alternative

Medicine, 2015, 1-9.

https://doi.org/10.1155/2015/506413

Thiericke, R. (2000). Drug discovery from

Nature: Automated high-quality

sample preparation. Journal of

Analytical Methods in Chemistry,

22(5), 149-157.

Tsai, C.-E., \& Lin, L.-H. (2019). DPPH scavenging capacity of extracts from Camellia seed dregs using polyol compounds as solvents. Heliyon, 5(8), e02315.

https://doi.org/10.1016/j.heliyon.201 9.e02315

Wahyuningrum, R., Utami, P. I., Dhiani,

B. A., Kumalasari, M., \&

Kusumawardani, R. S. (2016).

Screening of Potential Free Radicals

Scavenger and Antibacterial

Activities of Purwoceng (Pimpinella alpina Molk). Tropical Life Sciences

Research, 27(3), 161-166.

https://doi.org/10.21315/tlsr2016.27. 3.22

Wink, M. (2015). Modes of Action of

Herbal Medicines and Plant

Secondary Metabolites. Medicines, 2(3), 251-286.

https://doi.org/10.3390/medicines20 30251
Wulandari, L., Nugraha, A. S., \& Azhari, N. P. (2020). Penentuan Aktivitas Antioksidan dan Antidiabetes Ekstrak Daun Kepundung (Baccaurea racemosa Muell.Arg.) secara In Vitro. 07(01), 7.

Yeo, J., \& Shahidi, F. (2019). Critical ReEvaluation of DPPH assay: Presence of Pigments Affects the Results. Journal of Agricultural and Food Chemistry, 67(26), 7526-7529. https://doi.org/10.1021/acs.jafc.9b02 462

Zhang, Y.-J., Gan, R.-Y., Li, S., Zhou, Y., Li, A.-N., Xu, D.-P., \& Li, H.-B. (2015). Antioxidant Phytochemicals for the Prevention and Treatment of Chronic Diseases. Molecules, 20(12), 21138-21156. https://doi.org/10.3390/molecules20 1219753

Zhu, J., Yi, X., Zhang, J., Chen, S., \& Wu, Y. (2017). Chemical profiling and antioxidant evaluation of Yangxinshi Tablet by HPLC-ESIQ-TOF-MS/MS combined with DPPH assay. Journal of Chromatography B, 1060, 262-271. https://doi.org/10.1016/j.jchromb.20 17.06.022

Zulqarnain, Rahim A, Ahmad K, Ullah F, Ullah H, \& Nishan U. (2015). In vitro antibacterial activity of selected medicinal plants from lower Himalayas. 28(2), 581-58 